\title{
Biostratigraphy and Paleoenvironment of Bolivina Fauna from the Niger Delta, Nigeria
}

\author{
E. O. Obiosio ${ }^{1}$ \\ ${ }^{1}$ Department of Geology, Ahmadu Bello University, Zaria, Nigeria \\ Correspondence: E. O. Obiosio, Department of Geology, Ahmadu Bello University, Zaria, Nigeria. E-mail: \\ enamob@yahoo.com; eoobiosio@abu.edu.ng
}

Received: November 27, 2012 Accepted: January 28, 2013 Online Published: March 11, 2013

doi:10.5539/esr.v2n2p80

URL: http://dx.doi.org/10.5539/esr.v2n2p80

\begin{abstract}
A rich Bolivina assemblage occurs in the onshore Tonjor-1 well of Niger Delta; eighteen species are reported for the first time. Some index planktonic foraminifera allowed a late Early Eocene age assignation, in addition to some Bolivina species that are known to be restricted to samples from the studied intervals. The Bolivina species recovered permits the subdivision of the succession into one taxon and interval range zones respectively and two concurrent subzones. The interval zone is Bolivina ottaensis Reyment; while the taxon zone is Bolivina attenuata Cushman. The concurrent sub-zones are Bolivina foliacea Sellier de Civrieux and Bolivina jacksonensis Cushman and Applin. The planktonic foraminifers associated with the bolivinids are namely, Acarinina pentacamerata (subbotina), A. psuedotopilensis (Subbotina), Pseudohastigerina wilcoxensis (Cushman and Ponton) and Globigerina officinalis Subbotina which permits the late Early Eocene dating of these zones. Stratigraphic diversity variation of the bolivinds allowed the recognition of late Early Eocene marine transgression which correlates with the global timing of Early Eocene transgression. The presence of strong costae, and larger test suggests a deposition in a well oxygenated slope to bathyal environment.
\end{abstract}

Keywords: Bolivinids, Niger Delta, Agbada, Gulf of Guinea, planktonic foraminifera, first occurrence datum (FAD), last occurrence datum (LAD)

\section{Introduction}

The Niger Delta basin is situated in the Gulf of Guinea, Central West Africa, into which it progrades (Figure 1). The delta is considered one of the most prolific hydrocarbon provinces in the world hosting giant oil fields both onshore and offshore. Hydrocarbon exploration in the Niger Delta dated back to 1950's. This exploration and other investigation have contributed to documented stratigraphic and micropaleontologic data base for the region. Researches in micropaleontology has gained importance owing to increase in exploration for hydrocarbons. The petroleum industry in Nigeria have described and adopted informal zonation which is largely unpublished (Evamy et al., 1978). Benthonic foraminiferal assemblages of the Niger have been extensively published, however, the documentation of Bolivina has remain unsatisfactory. Petters (1982) reported 5 Bolivina species; Brun et al. (1984) reported less than ten. Subsequently, the oil industry identified about fifteen bolivinids to generic level.

The aim of this paper is to present a glimpse of the rich Bolivina assemblage by establishing biostratigraphic zonation and assess their palaeoenvironmental significance. 


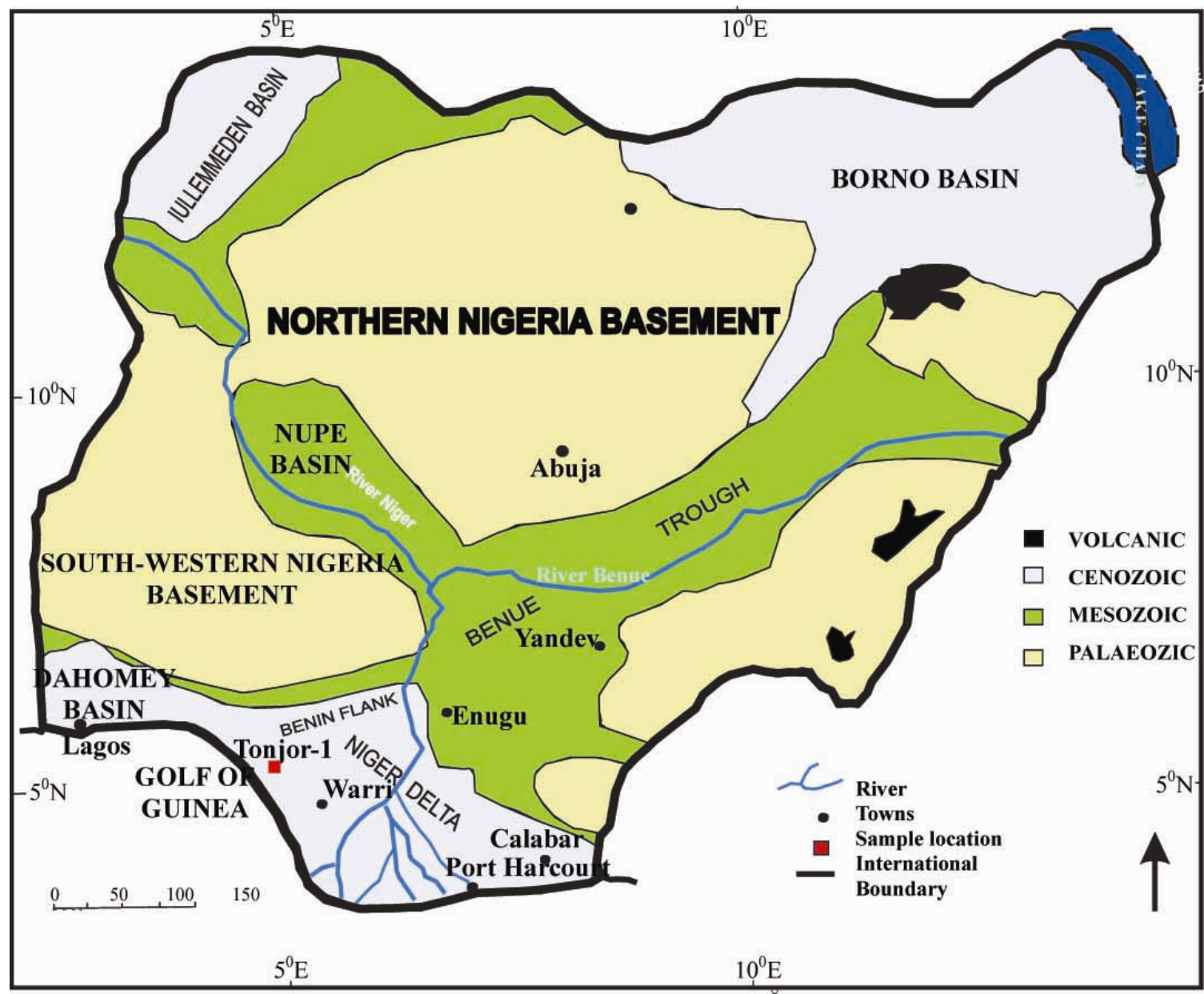

Figure 1. Geological map of Nigeria showing sample locations (Modified from Geological Survey of Nigeria, 1974)

\section{Geological Setting}

The geometry of the Niger Delta is controlled by the Chain and Charcot Fracture Zones of the Equatorial Atlantic Ocean (Emery et al., 1975). These zones confined clastic fill reaching some 12,000 $\mathrm{m}$ in thickness, the break-up of the central African - South American part of Gondwana took place along rift zones that met in a triple junction in the area of the Gulf of Guinea now occupied by the Niger Delta (Burke et al., 1971; Weber \& Daukoru, 1975; Whiteman, 1982). The area which followed the Equatorial and South Atlantic Ocean margins developed into the oceans, whereas the third, failed arm is represented by the Benue Trough.

During the rift phase the first sediments of the Cretaceous to Tertiary cycle accumulated. The oldest of these has been dated as Albian (Doust \& Omatsola, 1989). Thick successions of marine and marginal marine clastics and carbonates were deposited in a series of transgressive and regressive phases from Cretaceous to Tertiary (Murat, 1972; Weber \& Daukoru, 1975; Stoneley, 1966, Short \& Stauble, 1967). Vertical sections through the Niger Delta shows three units that are regarded as successive, diachronous prograding depositional facies namely the Akata, Agbada and Benin formations (Avbobvo, 1978; Evamy et al., 1987; Doust \& Omatsola, 1989; Kulke, 1995; Figure 2). The Akata Formation is composed of thick shale sequences and may contain south turbidite sands. The Agbada Formation consists of paralic siliclastics. The Benin Formation is composed of continental deposits. 


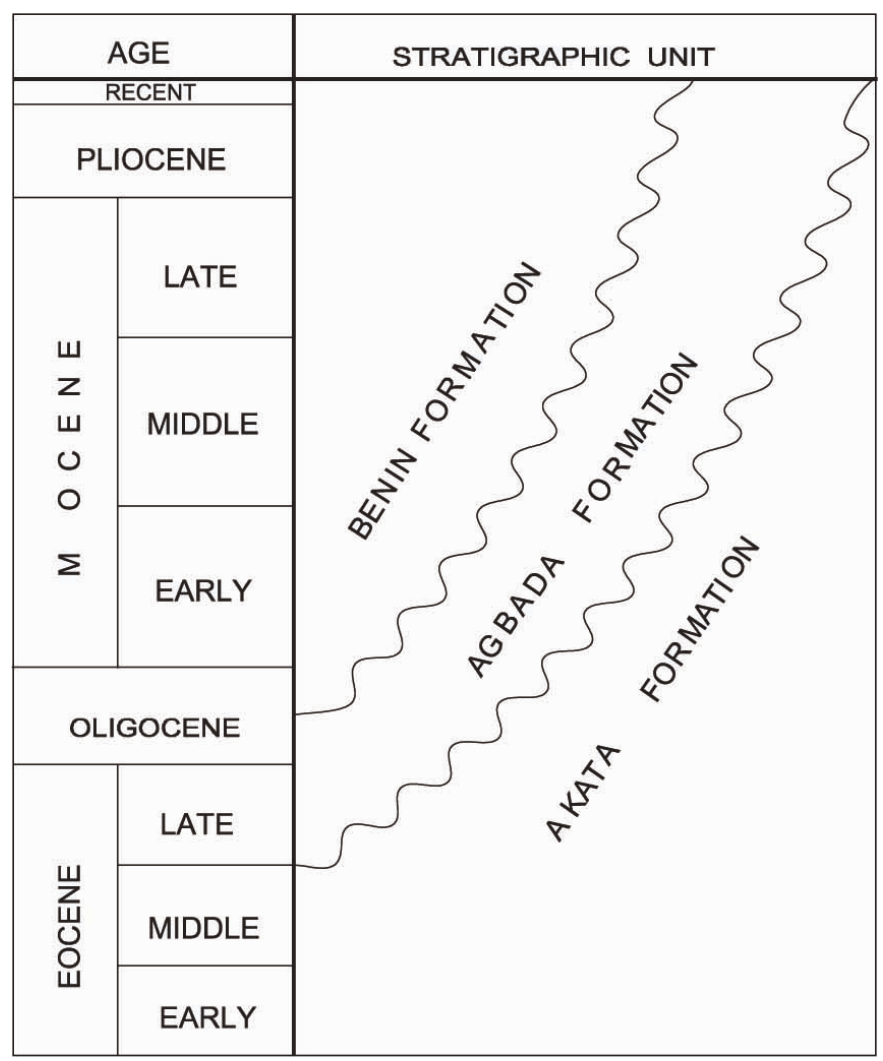

Figure 2. Stratigraphic units in the Niger Delta and their ages (Modified from Short \& Staube, 1967; Schumberger, 1985)

\section{Materials and Methods}

Ditch cuttings for the study were available from 2385 to $2535 \mathrm{~m}$ from Tonjor-1 well drilled by Phillips Oil Company of Nigeria. Seventeen ditch cutting samples were processed for their foraminiferal content, using standard micropaleontological techniques (Pessagno, 1967; Zingula, 1968; Brasier, 1980). Samples were disaggregated by heating in a solution of sodium carbonate and distilled water, then were wet-sieved through a 63 -micron (230-mesh) sieve, to retain foraminifera. Sieved samples were dried in an oven set at $60^{\circ} \mathrm{C}$. Samples were examined on a micropaleontological picking tray with a Fisher Scientific binocular microscopic. Digital photomicrographs were taken with a Nikon SMZ 1500 binocular stereomicroscope.

The bolivinids were mounted on microfossils slides and sorted into recognizable species. The quality of preservation of the specimens is good which made it possible to determine species ranges. Loeblich and Tappan (1987) generic classification was followed for generic assignment. Identification at the species level are based on Sellier de Civrieux (1976), Petters (1982), Bolli et al. (1994), Jones (1994) and Ellis and Messina Catalogue (Online version; http://www.micropress.org). Taxonomic descriptions of the bolivinids mentioned in this article are not presented here. All original species descriptions have been checked in the Ellis and Messina catalogue.

\section{Lithostratigraphy}

The section from Tonjor-1 well contains a single lithostratigraphic unit, the Agbada Formation. The available thickness of sediments belonging to the formation is $180 \mathrm{~m}$. The formation is characterized by a grey shale with sandy levels (Figure 3). 


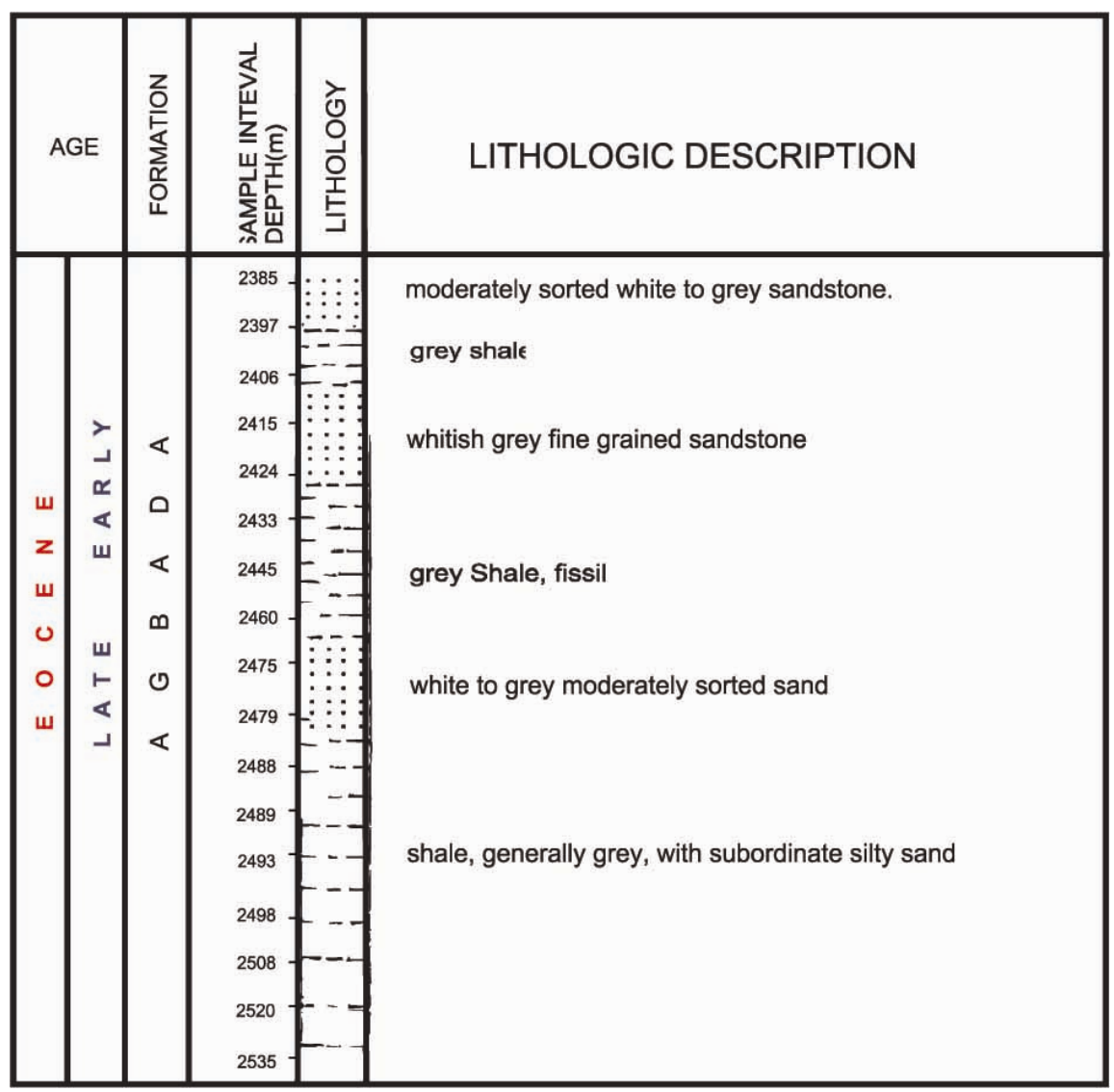

Figure 3. Lithostraigraphy of Tonjor-1 well

\section{Bolivina Fauna}

The microfaunal character of forms is indicated by a fairly abundant bolivinids and sparse planktonic foraminifera. Planktonic foraminifera were used as controls in constraining the stratigraphic ranges of the bolivinids. A total of twenty-three species of Bolivina were identified, out of which eighteen are reported for the first time. Species reported for the first in the Niger Delta are: Bolivina midwayensis Cushman, $B$. striatella Cushman, B. jacksonensis Cushman and Applin, B. inflata Heron-Allen and Farland, B. paralica Perconig, $B$. foliacea Sellier de Civrieux, B. britannica MacFadyen, B. beyrichi - carinata Hantken, B. sulphurensis Cushman and Adams, B. attenuata Cushman, B. bituminosa Spandel, B. crenulata Cushman, B. ignara Cushman and Stone, B. danvillensis Howe and Wallace, B. simplex Cushman and Renz, B. aenariensis (Costa), $B$. caudriae Cushman and Renz, B. imperatrix Graham de Klasz and Rerat. Stratigraphic distribution chart of these bolivinid species is presented in Figure 4 and steromicrographs of bolivinids and planktonic species are presented in Figures 6-8. 


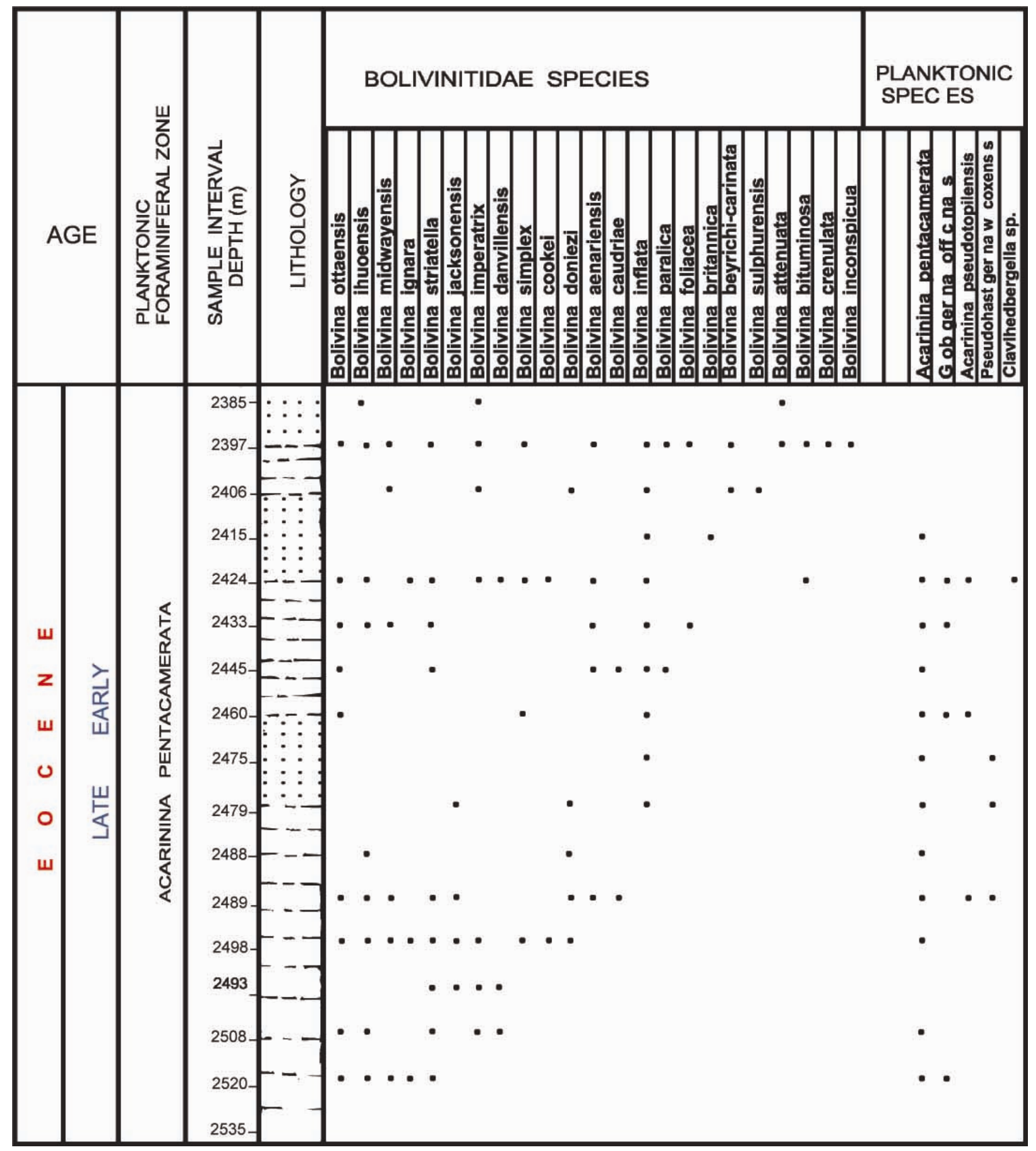

Figure 4. Stratigraphic distribution chart of Bolivina and planktonic foraminiferal species

\section{Biostratigraphy}

Benthonic foraminifera, which the Bolivina belong to are generally long-ranged. However, some of the bolivinid species recovered from Tonjor-1 well are stratigraphically restricted. Those planktonic foraminiferal species that are age diagnostic were used for stratigraphical controls.

The analysis of the bolivinids was carried out using standard biostratigraphic methods and biozones distinguished according to the International Stratigraphic Guide (Hedberg, 1976; Murphy \& Salvador, 1999). The stratigraphic range of the species are illustrated in Figure 5. The following biozones are proposed for the Tonjor-1 well. 


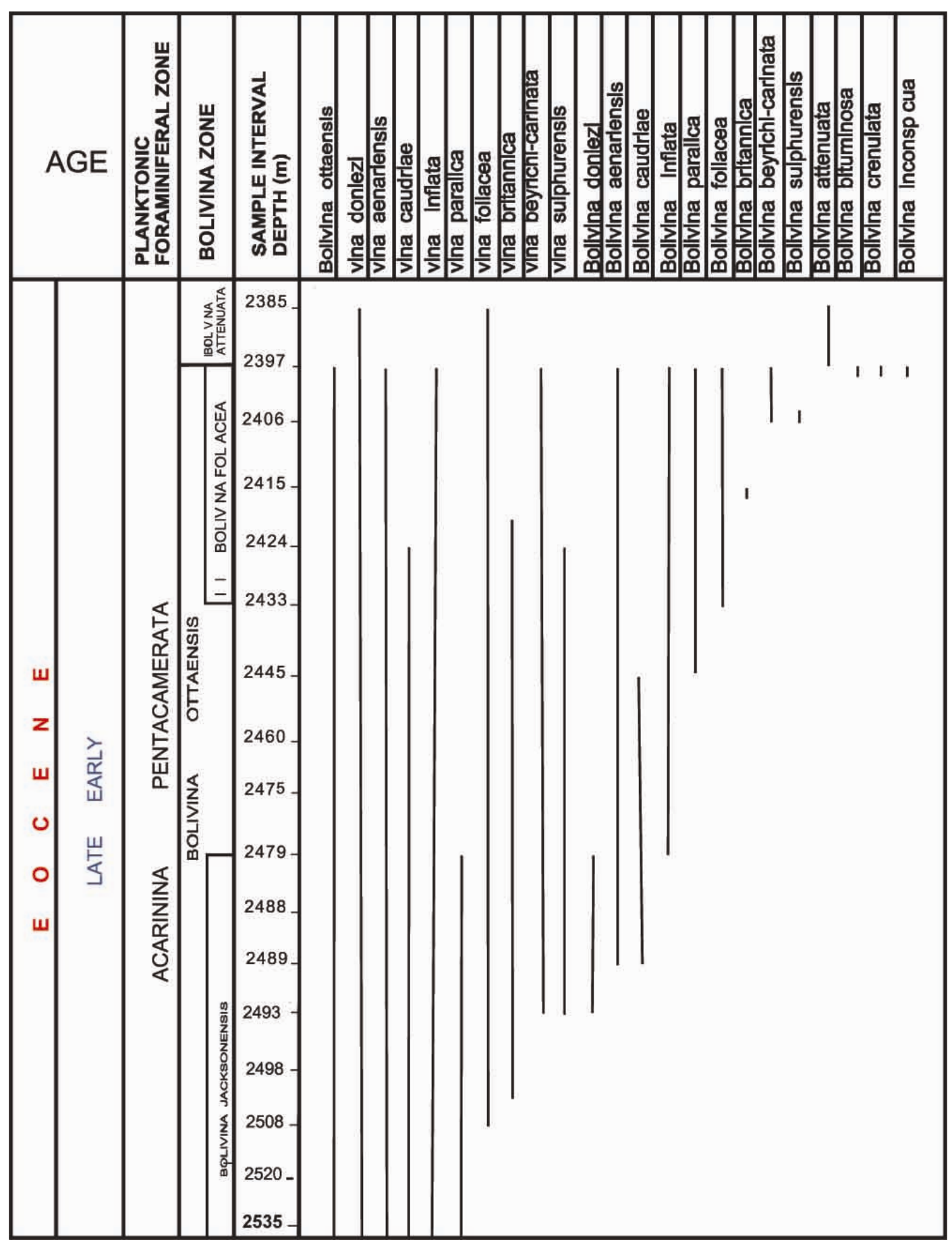

Figure 5. Range chart of Bolivina species in Tonjor-1 well 


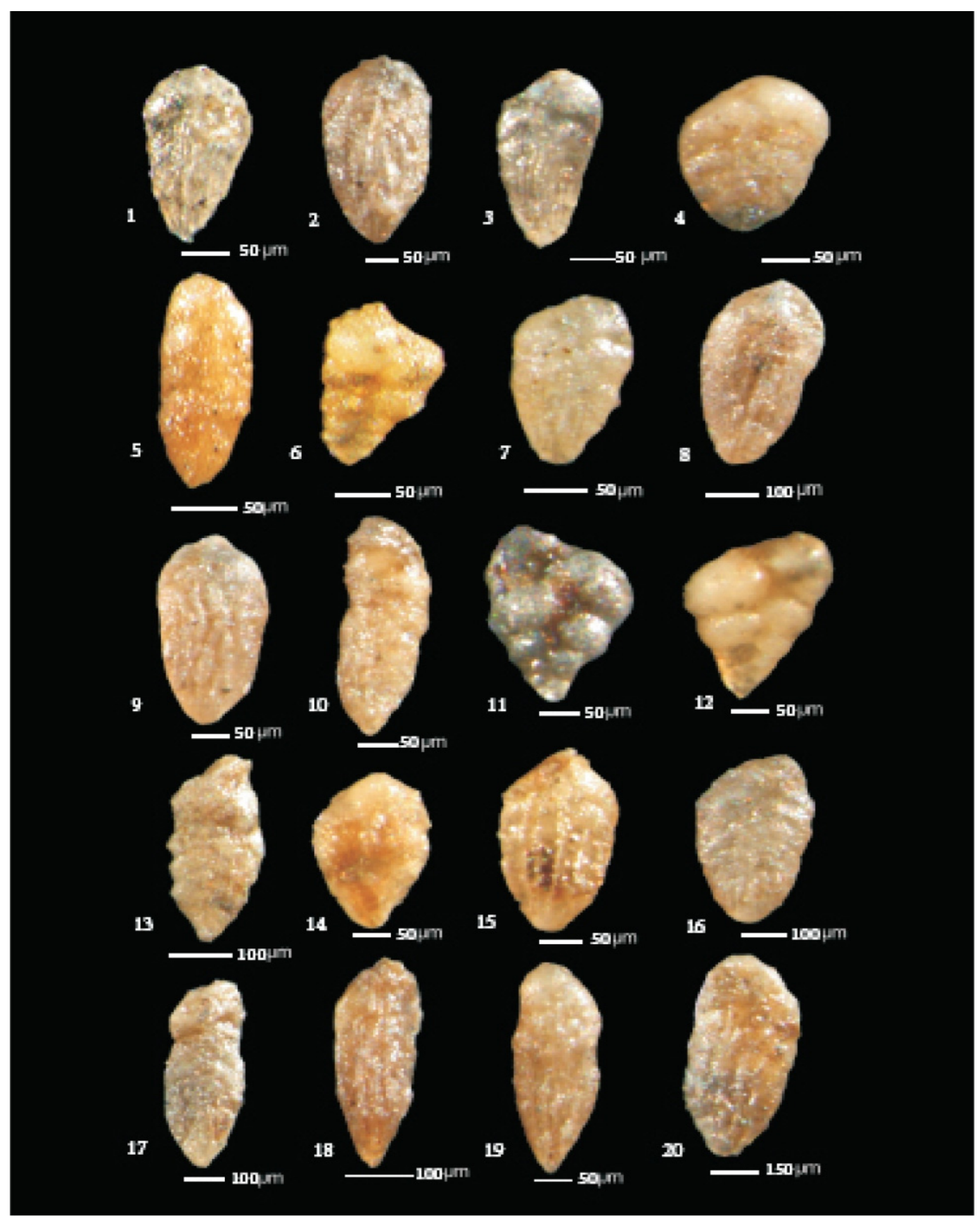

Figure 6. 1) Bolivina crenulata; 2, 19) Bolivina ottaensis; 3) Bolivina bituminosa; 4) Bolivina attenuata; 5) Bolivina sulphurensis; 6) Bolivina britannica; 7) Bolivina jacksonensis; 8) Bolivina caudriae; 9) Bolivina danvillensis; 10) Bolivina striatella; 11 \& 12) Bolivina inflata; 13) Bolivina paralica; 14) Bolivina doniezi; 15) Bolivina inconspicua; 16) Bolivina simplex; 17) Bolivina midwayensis; 18) Bolivina beyrichi carinata; 20) Bolivina cookie 


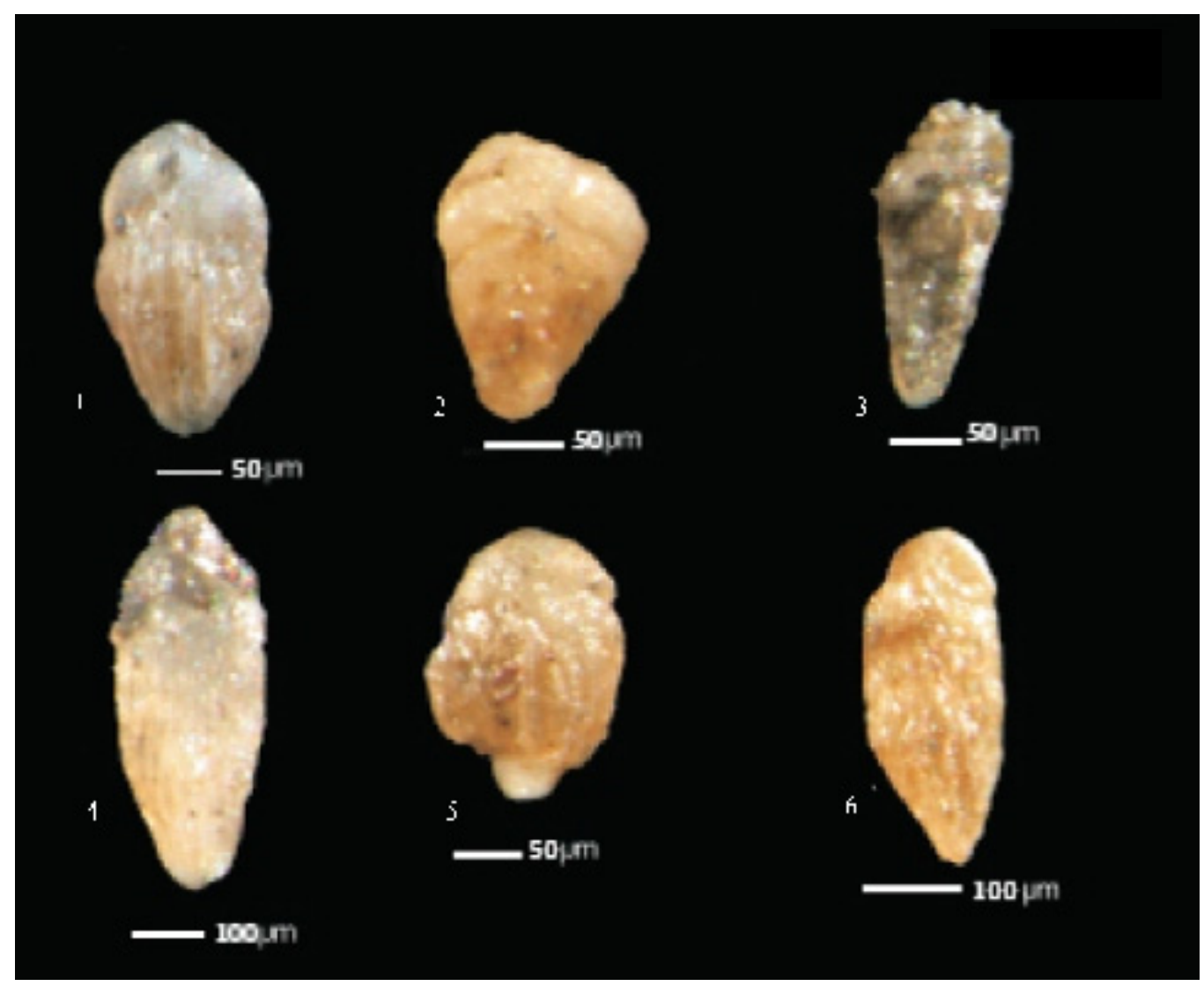

Figure 7. 1, 5, 6) Bolivina ottaensis; 2) Bolivina foliacea; 3) Bolivina aenariensis; 4) Bolivina imperatrix 


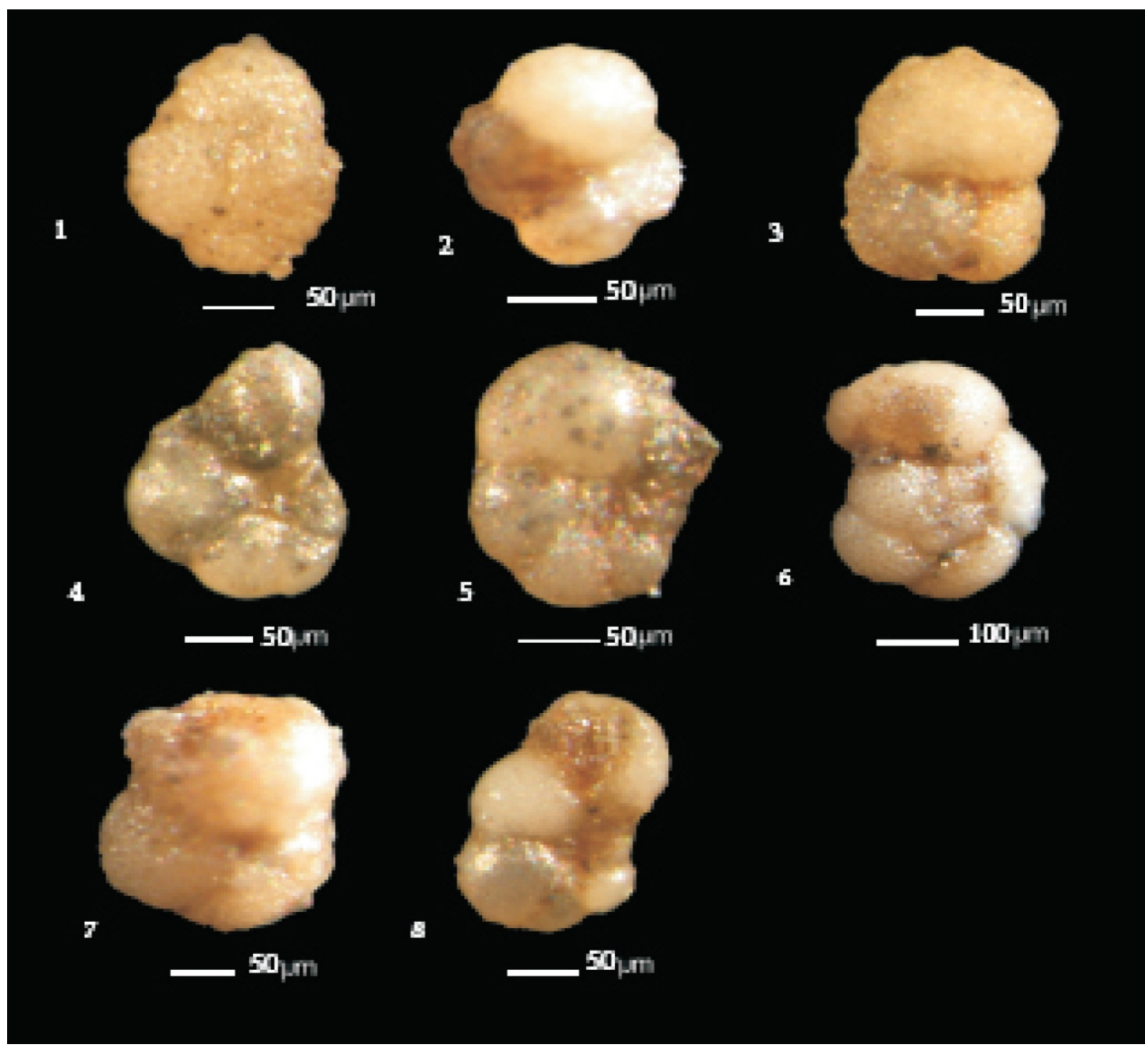

Figure 8.1 \& 2) Acarinina pentacamerata; 3) Globigerina officinalis; 4) Clavihedbergella sp.; 5 \& 6) Acarinina pseudotopilensis; 7) Pseudohastigerina wilcoxensis; 8) Pseudohastigerina wilcoxensis

i) Bolivina ottaensis Interval zone

a) Bolivina foliacea Concurrent-range-subzone

b) Bolivina jacksonensis Concurrent-range-subzone

ii) Bolivina attenuata Taxon range zone

\section{1) Bolivina ottaensis Interval-Zone}

The base of this zone is defined by the first appearance datum (FAD) of Bolivina ottaensis (Figure 5). The top is marked by the first appearance of Bolivina attenuata, which also coincides with the bioevent (appearance and disappearance) of Bolivina bituminosa, Bolivina crenulata and Bolivina inconspicua, an event that may be due ecologic factors. Species restricted to this zone are: Bolivina ottaensis, $B$. midwayensis, $B$. ignara, $B$. striatella, $B$. jacksonensis, B. doniezi, B. foliacea, B. britannica, B. beyrichi-carinata, B. sulphurensis, B. bituminosa, B. crenulata and $B$. inconspicua. The following species appear in this zone but range upward into the next zone: Bolivina ihuoensis, B. imperatrix, B. danvillensis, B. simplex, B. cookie, B. aenariensis, B. caudriae, B. inflata, and B. paralica. The association of these bolivinids with Acarinina pentacamerata, A. pseudotopilensis and Pseudohastigerina wilcoxensis suggests a late Early Eocene age for this zone and correlates with the Acarinina 
pentacamerata zone (Blow 1969; Stainforth et al., 1975; Petters, 1983). A. pseudotopilensis has received a widespread recognition as a zonal index for Early Eocene (Subbotina, 1947; Loeblich \& Tappan, 1957; Jenkins, 1971). The appearance of Pseudohastigerina wilcoxensis was used to define the base of Eocene (Berggren, 1971). Globigerina officinalis has a known range of Eocene to Oligocene (Subbotina, 1953). This zone is represented in the Agbada Formation penetrated by the Tonjor-1 well at depths between 2397 and $2535 \mathrm{~m}$.

2) Bolivina jacksonensis Concurrent Sub-Zone

The FAD of Bolivina jacksonensis marks the base of this zone. The top is coincident with the LADs of two species which are restricted to the sub-zone, namely the

concurrent part of the ranges of Bolivina doniezi and Bolivina jacksonensis (Figure 5). This sub-zone embraces the Agbada Formation between depths of 2479 and $2535 \mathrm{~m}$ in the Tonjor- 1 well. The sub-zone is dated late Early Eocene based on the presence of the planktonic foraminifer, Acarinina pentacamerata.

\section{3) Bolivina foliacea Concurrent Sub-Zone}

The base of the sub-zone is recognized by the FAD of Bolivina foliacea. The top is coincident with the LADs of several species which are restricted to this zone, namely the concurrent part of the ranges of Bolivina foliacea, $B$. bituminosa, B. crenulata, B. sulphurensis, B. inconspicua, B. britannica and B. beyrichi-carinata (Figure 5). This sub-zone occurs within the Agbada Formation between depths of 2397 and $2433 \mathrm{~m}$ in the Tonjor-1 well and is of late Early Eocene based on the associated planktonic foraminifer, Acarinina pentacamerata.

\section{4) Bolivina attenuata Taxon Range-Zone}

The zone is marked by the entire occurrence of Bolivina attenuata; base of this zone is marked by the FAD of Bolivina attenuata which coincides with the top of the Bolivina ottaensis interval-zone and with the bioevent (sudden appearance and disappearance) of Bolivina bitumunosa, Bolivina crenulata and B. inconspicua. The top of the zone is marked by the lowest occurrence of the species. Species restricted to this zone is Bolivina attenuata. This zone has a probable range within limits of late Early Eocene. The Bolivina attenuata Taxon zone embraces the Agbada Formation between depths of 2385 to $2397 \mathrm{~m}$.

\section{Paleoenvironment}

Bolivinid assemblages from Tonjor-1 well were examined to determine the depositional environment. Paleoenvironmental interpretations, mainly bathymetric and oxygenation levels determined in this study are based upon comparison of morphological features with recent analogues. Bolivinid species diversity is qualitatively applied to interpret changes in sea level.

\subsection{Bathymetry}

Morphological comparisons of forms have allowed a broad categorization of bathymetry in the studied well. Smith (1963) noted that bolivinid faunas found in slope environments generally show larger test sizes compared to those of the inner neritic zone. Bandy (1960) also reported that costate bolivinids become dominant in the outer shelf and upper bathyal zones. Other characters exhibited by bathyal species are coarse perforations, strong striae and heavy limbation. Costae paralleling the longitudinal axis occur in forms occupying the outer neritic and much of the bathyal zone.

Bolivinid species from the Eocene in the studied well (Tonjor-1) consist of forms that have dominantly large tests adorned with costae. Bolivinids in this category are Bolivina ottaensis, Bolivina ihuoensis, Bolivina imperatrix, Bolivina simplex, Bolivina striatella, Bolivina ignara, Bolivina foliacea, Bolivina inconspicua,. These species probably habited slope to bathyal water.

\subsection{Oxygen}

Lutze (1962; 1964) studied Bolivina spissa Cushman, Bolivina pseudobeyrichi Cushman and Bolivina argentea Cushman, all benthic foraminiferal species living off the coast of southern California. He demonstrated that within one species there may be great variation in width/length ratios, in the development of costae, in the length of an apical spine, in the amount of sutural limbation, in the proportion of pore free areas on chambers, in imbrications of chambers and in the development of keeled edges. He considered one of the primary controlling factors to be the level of oxygen concentration in the bottom water of basins. High oxygen levels were associated with the secretion of more surface sculpture, such as more spines, more costae or larger keels, whereas very low oxygen concentrations resulted in the marked reduction or absence of many kinds of surface sculpture.

The Eocene specimens from the studied intervals have well developed costae, limbation, keels and carinae which suggest that the environment was well oxygenated. 


\subsection{Sea Level}

Stratigraphical variation in foraminiferal species diversity was considered to indicate changes in sea level by Walton (1964). Petters (1983) recognized that major transgressive peak occurred in Early Eocene of the Gulf of Guinea based on planktonic foraminifera fauna. The occurrence of planktonic foraminiferal species associated with bolivinids of Tonjor-1 in this study correlate the influence of Early Eocene transgression in the Niger Delta region. A bolivinid major diversity peak (Figure 9) correlate the timing for the transgressive phase in the Niger Delta with the global Early Eocene transgression.

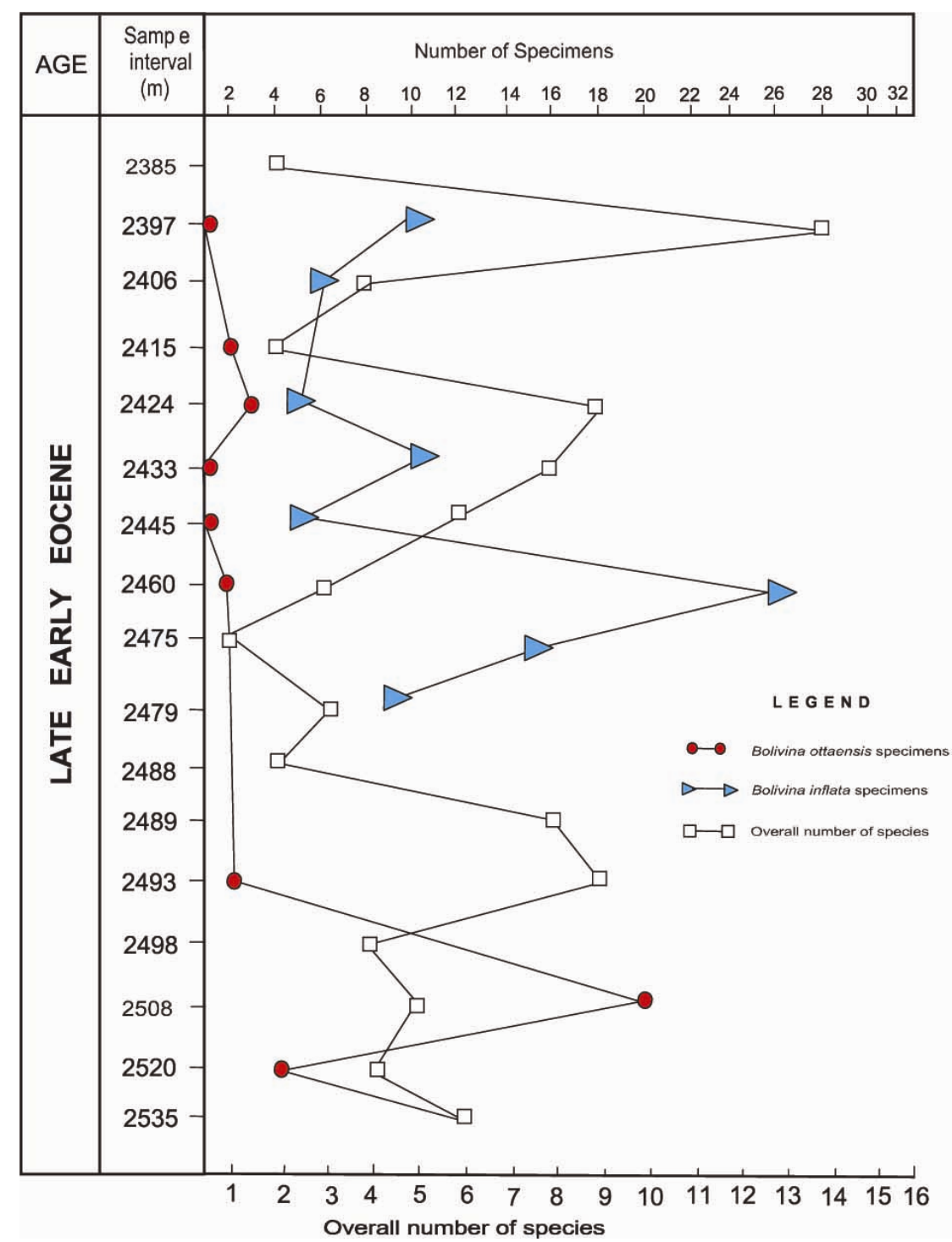

Figure 9. Abundance of Bolivina Species in Tonjor-1 well

\section{Conclusion}

Foraminifers belonging to the family Bolivinitidae in the Niger Delta basin, Nigeria have allowed the subdivision of late Early Eocene succession into interval range zone, Bolivina ottaensis; taxon zone, Bolivina attenuata, and 2 concurrent sub-zones, Bolivina foliacea and Bolivina jacksonensis. Eighteen species of Bolivina are reported for the first time in the Niger Delta basin.

Heavily costate ornamentations on the test of the bolivinids suggest deposition in water depth ranging between slope to bathyal under a well oxygenated condition. Bolivinid species diversity permits the recognition of regional Early Eocene transgression. 


\section{Acknowledgement}

The author is indebted to Prof. Dr. Wolfgang Kuhnt and Dr. Anne Holbourn of the Christian - Albrechts University Kiel, Germany for the opportunity to use stereomicroscope to produce digital photomicrographs and Mac Arthur Foundation for support.

\section{References}

Avbobvo, A. A. (1978). Tertiary lithostratigraphy of Niger Delta. American Association of Petroleum Geologists Bulletin, 62, 295-306.

Bandy, O. L. (1960). General correlation of foraminiferal structure with environment. $21^{\text {st }}$ lnternational Geological Congress Proceedings, Norden, 22, 1-19.

Berggren, W. A. (1960). Some planktonic foraminifera from Lower Eocene (Ypresian) of Denmark and northwestern Germany. Acta. Univ. Stockholm Contr. Geol., 5(3), 41-108.

Blow, W. H. (1969). Late Middle Eocene to Recent planktonic foraminiferal biostratigraphy. $1^{\text {st }}$ International Conference Planktonic Microfossils Proceedings, Geneva 1967, 1, 199-422.

Bolli, H. M., Beckman, J. R., \& Sanders, J. B. (1994). Benthic foraminiferal biostratigraphy of the South Caribbean region (p. 408). Cambridge: Cambridge University Press. http://dx.doi.org/10.1017/CBO9780511564406

Brasier, M. D. (1980). Microfossils (p. 193). London: George Allen and Unwin.

Brun, L., Chierici, M. A., \& Meijer, M. (1984). Evolution and morphological variations of the principal species of Bolivinitidae in the Tertiary of the Gulf of Guinea. Géologie Méditerranéenne, XI, 13-57.

Burke, K., Dessauvagie, T. F. J., \& Whiteman, A. J. (1971). Opening of the Gulf of Guinea and geological history of the Benue depression and Niger Delta. Nature, 233, 51-55.

Doust, H., \& Omatsola, E. (1989). Niger Delta. American Association of Petroleum Geologists Memoir, 48, 201-238.

Emery, K. O., Uchupi, E., Phillips, J., Brown, C., \& Mascle, J. (1975). Continental margin of western African. Angola to Sierra-Leona. Amer. Assoc. Petrol. Geol. Bull., 59, 2209-2265.

Evamy, B. D., Harembourne, J., Kamerling, P., Knaap, W., Molloy, F. A., \& Rowlands, P. H. (1978). Hydrocarbon habitat of Tertiary Niger Delta. American Association Petroleum Geologists Bulletin, 62(1), $1-39$.

Geological Survey of Nigeria. (1974). Geological map of Nigeria. Scale 1: 2,000,000. Geological Survey Division, Federal Ministry of Mines and Power, Nigeria.

Hedberg, H. D. (1976). International stratigraphic guide. A guide to stratigraphic classification, terminology, and procedure (p. 200). New York: Wiley.

Jenkins, D. G. (1971). New Zealand Cenozoic Planktonic Foraminifera. New Zealand Geological Survey Paleontology Bulletin, 42, 278.

Jones, R. W. (1994). The Challenger Foraminifera (pp. 142). Oxford: Oxford University Press.

Kulke, H. (1995). Nigeria, in, H. Kulke, (Eds.), Regional Petroleum Geology of the World (pp. 143-172). Part II: Africa, America, Australia and Antarctica. Berlin: Gebrüder Burntraeger.

Loeblich, A. R., \& Tappan, H. (1957). Planktonic foraminifera of Paleocene and early Eocene age from the Gulf and Atlantic Coastal Plains. U.S nat. Mus. Bull., 215, 173-198.

Loeblich, A. R., Jr., \& Tappan, H. (1987). Foraminifera and their classification (p. 970). New York: Van Nastrand Reinhold.

Lutze, G. F. (1962). Variationsstatistik und Ökologie bei rezenten Foraminiferen. Paläeontologische Zeitschrift, $36,252-264$.

Lutze, G. F. (1964). Statistical investigations on the variability of Bolivina argentea Cushman. Cushman Foundation for Foraminiferal Research Contribution, 15, 105-116.

Micropress Project. (2007). Ellis and Messina Online Catalogue of Foraminifera. New York: Micropress. 
Murat, R. C. (1972). Stratigraphy and Paleogeography of the Cretaceous and Lower Tertiary in Southern Nigeria. In: T. F. J. Dessauvagie, \& A. J. Whiteman (Eds.), African Geology (pp. 251-266). Ibadan: Ibadan University Press.

Murphy, M. A., \& Salvador, A. (1999). International Stratigraphic Guides-An abridged version. Episodes, 22(4), 255-271.

Pessagno, E. A. Jr. (1967). Upper Cretaceous stratigraphy of the western Gulf Coastal Plain. Palaeontographica Americana, 5, 245-445.

Petters, S. W. (1982). Central West African Cretaceous-Tertiary benthic Foraminifera and stratigraphy. Paleontographica A, 179, 1-104.

Petters, S. W. (1983). Gulf of Guinea planktonic foraminiferal biochronology and geological history of the South Atlantic. Journal of Foraminiferal Research, 13, 32-59. http://dx.doi.org/10.2113/gsjfr.13.1.32

Schlumberger. (1985). Well Evaluation Conference, Nigeria (p. 290). Lagos: Schlumberger.

Sellier de Civrieux, J. M. (1976). Estudio sistemático y ecológico de las Bolivinitidae recientes de Venezulea. Cuadernos Oceanografico, 5, 3-43.

Short, K. C., \& Stauble, A. J. (1967). Outline of geology of Niger Delta. American Association of Petroleum Geologists Bulletin, 51, 761-779.

Smith, P. B. (1963). Quantitative and qualitative analysis of the family Bolivinidae. In: Recent Foraminifera of Central America. United States Geological Survey Professional Paper, 429(A), A1-A39.

Stacher, P. (1995). Present understanding of the Niger Delta hydrocarbon habitat. In M. N. Oti \& G. Postma (Eds.), Geology of Deltas (pp. 257-267). Rotterdam: Balkema.

Stainforth, R. M., Lamb, J. L., Luterbacher, H., Beard, J. H. \& Jeffords, R. M. (1975). Cenozoic planktonic foraminiferal zonation and characteristics of index forms. University of Kansas Paleontological Contribution, 62, 1-425.

Stoneley, R. (1966). The Niger delta region in the light of the theory of continental drift. Geological Magazine, 105, 385-397. http://dx.doi.org/10.1017/S0016756800053978

Subbotina, N. N. (1947). Foraminifers of the Danian and Paleogene deposits of the northern Cancasus. Microfauna of the Caucasus Emba region and Central Asia. Geol., Razved. Inst. Trudy. pp. 39-160.

Subbotina, N. N. (1953). Fossil foraminifers of the USSR: Globigerinidae, Globorotalüdae, Hantkeninidae Turdy. VNIGRI, 76, 1-291. (in Russian). Translated into English by E. Lees, published by Collets Ltd., London and Willingborough.

Walton, W. R. (1964). Recent foraminiferal ecology and paleoecology. In J. Imbrie, \& N. D. Newell (Eds.), Approaches to Palaeoecology (pp. 151-237). New York: Wiley.

Weber, K. J., \& Daukoru, E. (1975). Petroleum geology of the Niger Delta. 9th World Petroleum Congress, Tokyo, Proceedings, 2, 209-221.

Whiteman, A. (1982). Nigeria-Its Petroleum Geology, Resources and Potential (p. 176; p. 238). London: Graham and Trotman. http://dx.doi.org/10.1007/978-94-009-7361-9

Zingula, R. P. (1968). A new breakthrough in sample washing. Journal of Paleontology, 42(4), 1092. 